\title{
Butterfly Woods, The Wilds, anoptimal habitat of dictyostelidcellular slime molds in Ohio
}

\section{Cavender $\mathrm{JC}^{1}$ and Cavender $\mathrm{ND}^{2,3^{*}}$}

\author{
${ }^{1}$ Department of Environmental and Plant Biology, Ohio University, Athens, Ohio 45701 \\ ${ }^{2}$ The Wilds, Cumberland, Ohio 43701 \\ ${ }^{3}$ Present address: The Morton Arboretum, 4100 Illinois Route 53, Lisle, IL 60532; ncavender@mortonarb.org
}

Cavender JC, Cavender ND 2013 - Butterfly Woods, The Wilds, an optimal habitat of dictyostelidcellular slime molds in Ohio. Mycosphere 4(2), 282-290, Doi 10.5943/mycosphere/4/2/11

The occurrence and distribution of cellular slime molds (CSM) in Ohio have been studied by J. Cavender, C. Hopka, C. Hammer, G. Kauffman, M. Stephenson, and N. Cavender over a 40-year period in order to discover environmental factors important for their ecological survival. Recently (2003) an unglaciated, mixed mesophytic, remnant forest patch, Butterfly Woods (BW) at The Wilds, Muskingum County, a forest which is now surrounded by reclaimed strip mines, was found to have the highest CSM diversity of the 119 sites sampled in Ohio. Nineteen species were found over a period of seven years of soil sample collecting. This compares with a total of 25 occurring in Ohio and is the largest number found so far in any single temperate deciduous forest ( $<40 \mathrm{ha})$ in the United States as well as world-wide. Abundance (relative density) of each species measured by the number of clones is very similar to that occurring statewide, but there are some interesting differences. Comparison with ecological distributions in Ohio is used to help explain the cooccurrence of so many species in BW. The reasons why BW is believed to be optimal for CSM biodiversity are: 1) unglaciated soil, unflooded by post glacial lakes; 2) soil with variable $\mathrm{pH}$, slightly acidic to neutral and derived from layered sandstone, limestone, and shale bedrock; 3) east to northeast slope; 4) favorable moisture regime and slightly changing soil conditions from top to bottom; 5) relatively high mixed mesophytic tree diversity as well as herb diversity providing varied microsites; 6) abundant organic matter and well-developed humus and litter layer conducive to bacterial growth; 7) a large ravine which provides increased environmental protection and helps renew nutrient levels; 8) some past disturbance around the borders from agriculture and mining; and 9) a large enough size to conserve CSM biodiversity.

Key words - Cellular slime mold diversity - environmental factors - microhabitat variation - soil conditions

\section{Article Information}

Received 17 February 2013

Accepted 22 March 2013

Published online 20 April 2013

*Corresponding Author:Nicole D. Cavender-e-mail-ncavender@mortonarb.org

\section{Introduction}

Cellular slime molds (CSM) are bacterivores and live in the surface layers of soils, particularly forest soils where they receive protection from the sun and wind and have a ready access to their food supply. Their identification, ecology, and distribution have been a focus of the NSF sponsored Global Biodiversity Inventory. In addition their evolution and phylogeny are actively being 
investigated (Schaap et al. 2006, Romeralo et al. 2011). They have been studied in forest soils of Ohio since 1970. An ecological (Cavender \& Hopka1986) and a taxonomic/ecological (Cavender \& Vadell 2006) study have been published. Hopka (1972) completed an MS thesis on the dictyostelids in Ohio. Eighty-two sites were sampled, most of them forests, along with some prairie and old field habitats. Sites were divided into eight habitat-association groupings: 1) prairie-old field; 2) beechhemlock; 3) beech-maple; 4) oak-hickory; 5) mixed oak; 6) mixed meso-phytic; 7) limestone gorges and floodplains; and 8) depressional swamp forests. Hopka collected 634 soil samples from 31 counties and isolated 25,318 clones of 10 species. Data calculated were clones per gram, frequency (percent occurrences within a site), and relative density (percent of clones of each species of the total clones at a site). Although Hopka did not make statistical comparisons, his data does show that species are responding to edaphic factors and that the distribution of each species is different, exhibiting habitat "preferences."

Hammer (1984) and Kauffman (1986) studied dictyostelids in Ohio agricultural soils where diversity is lower than in natural forest, while Stephenson (1995) investigated dictyostelid ecology at one Ohio site, the Ridges, in Athens. Cavender\&Hopka (1986) made a similar study to Hopka (1972) but used statistical analysis (Duncan's multiple range test and the LSD t-test). Eighty-five forest sites in eight physiographically defined environments: 1) unglaciatednorth slope; 2) unglaciated south slope; 3) limey glacial drift; 4) acid glacial drift; 5) glacial depression; 6) glaciated upland; 7) limestone ravine, and 8) sandstone ravine were sampled. Sixteen species were isolated. Eight species (Dictyosteliumminutum, D. discoideum, D. purpureum, D. polycephalum, D lacteum, Polysphondyliumviolaceum, P. pallidum, and Acytosteliumleptosomum) showed distinctive distribution patterns based on both importance values (sum of frequency, relative density, and presence [percent of sites/regime inhabited by a species]) and statistical analysis.

In total four major surveys involving sampling of Ohio forests have been made: Hopka, 1970 (65 sites); Cavender, 1981 (35 sites); Cavender, 1998 (26 sites); and the most recent survey (Cavender 2007-2009) in which 13 sites were sampled. Repeat collections were made at 20 sites and a total of 119 sites covering eight physiographic regimes and six forest associations in 41 of 88 counties have been sampled (Fig. 1). Several sites contained as many as 11 species (e.g., Dysart Woods, Belmont Co.) and one had 12 (Sheick Hollow). However, one site in particular, BW at The Wilds, produced 14 species from the first collections in 2003 and 19 to date. Several individual soil samples produced eight species and one had 10. This is higher than has been reported for any other individual site in Ohio or in the temperate deciduous forest world-wide. This site was selected for further sampling and study in order to better understand the soil environment which is optimal for dictyostelid CSM.

\section{Methods}

\section{Characteristics of the study area}

The Wilds is a large international conservation center located in the unglaciated Appalachian region of southeastern Ohio ( $\left.39^{\circ} 49^{\prime} 48^{\prime \prime} \mathrm{N}, 81^{\circ} 43^{\prime} 53^{\prime \prime} \mathrm{W}\right)$, and it has experienced over 60 years of disturbance from surface mining for coal, although some remnant forest patches remain. Those sampled in this study in addition to BW were Repelling, Beech Hollow, Miller, and Johnson Woods (Table 1). Inventories of the trees and shrubs, herbs, and soils have been made (Table 2). Twenty-six tree species and five shrub species have been identified along with 59 herbaceous species. The assemblage is diverse for Ohio and is classified as mixed mesophytic (Braun 1950). The woodland is $59,670 \mathrm{~m}^{2}$ (ca. $6 \mathrm{ha}$ ) and has a northeast slope (Fig. 1). One large ravine and two smaller ones dissect the slope and expose bedrock which is thin-bedded sandstone, shale, and siltstone interspersed with limestone, all of Pennsylvanian age (Stout 1918). Some of the derived soil characteristics are given in Table 2. Of particular interest is the soil $\mathrm{pH}$ which varies from 6.2 to 7.0, increasing down the slope. The A-horizon soil organic matter averages $17 \%$ and is covered by decomposing leaf litter. Altitude above sea level is $357 \mathrm{~m}$ at the top of the ridge. 


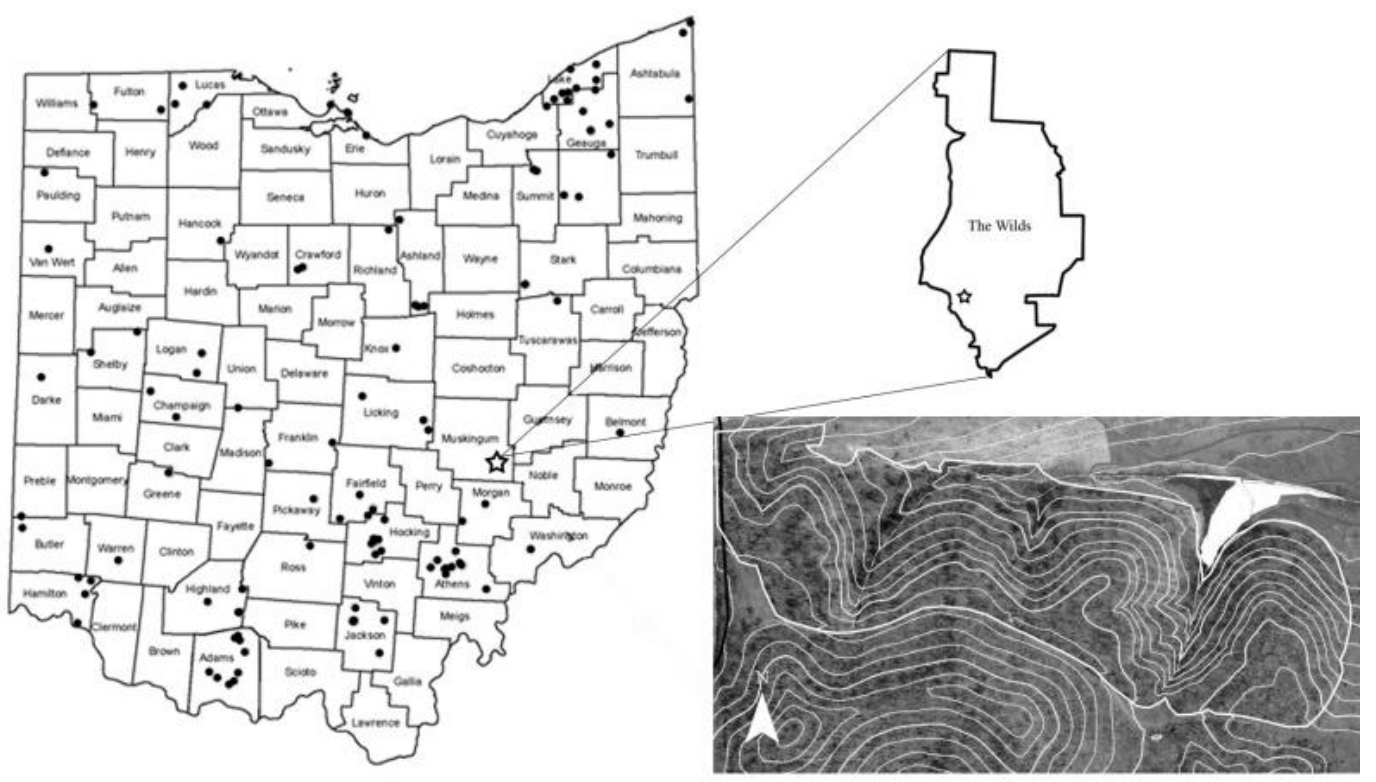

Fig. 1 - Dictyostelid cellular slime mold collection sites in Ohio. 119 sites in 41 of 88 counties have been sampled since 1970. Indicated by a star, Butterfly woods is located at The Wilds in Muskingum County, Ohio. A topographic map of Butterfly Woods is shown with 3-m contours and the ecological aspect is shown by the color photo.

Table 1 Cellular slime mold species found in remnant forests of The Wilds.

\begin{tabular}{|c|c|c|c|c|c|}
\hline \multirow[t]{2}{*}{ Species name } & \multicolumn{5}{|c|}{ Location } \\
\hline & $\begin{array}{l}\text { Beach } \\
\text { Hollow }\end{array}$ & $\begin{array}{c}\text { Butterfly } \\
\text { Woods }\end{array}$ & $\begin{array}{l}\text { Johnson } \\
\text { Woods }\end{array}$ & $\begin{array}{l}\text { Miller } \\
\text { Woods }\end{array}$ & $\begin{array}{c}\text { Rappelling } \\
\text { Woods }\end{array}$ \\
\hline Acytosteliumleptosomum & & $*$ & & $*$ & $*$ \\
\hline Dictyosteliumaureostipes & $*$ & $*$ & $*$ & $*$ & $*$ \\
\hline Dictyosteliumdiscoideum & $*$ & $*$ & & $*$ & $*$ \\
\hline Dictyosteliumgiganteum & $*$ & $*$ & $*$ & & \\
\hline Dictyosteliumimplicatum & $*$ & $*$ & & $*$ & $*$ \\
\hline Dictyosteliumlacteum & $*$ & * & & $*$ & * \\
\hline Dictyosteliumleptosomum & & * & & & \\
\hline Dictyosteliumminutum & $*$ & $*$ & & $*$ & $*$ \\
\hline Dictyosteliummucoroides & $*$ & $*$ & $*$ & $*$ & $*$ \\
\hline Dictyosteliumpolycarpum & & * & & & $*$ \\
\hline Dictyosteliumpurpureum & $*$ & $*$ & & $*$ & $*$ \\
\hline Dictyosteliumquercibrachium & & $*$ & & & \\
\hline Dictyostelium sp. 1 & & $*$ & & & \\
\hline Dictyostelium sp. 2 & & * & & $*$ & \\
\hline Dictyosteliumsphaerocephalum & & $*$ & & & \\
\hline Polysphondyliumcandidum & & $*$ & & & $*$ \\
\hline Polysphondyliumpallidum & $*$ & $*$ & & $*$ & $*$ \\
\hline Polysphondylium album & $*$ & $*$ & & $*$ & $*$ \\
\hline Polysphondyliumviolaceum & $*$ & $*$ & $*$ & $*$ & $*$ \\
\hline Total species & 11 & 19 & 4 & 12 & 13 \\
\hline \# of collections & 3 & 3 & 2 & 3 & 3 \\
\hline \# of samples & 14 & 16 & 10 & 19 & 16 \\
\hline
\end{tabular}




\section{Sampling}

When sampling Ohio forests, soil surface and humus samples were randomly collected and placed in plastic bags;5-10 samples were commonly collected from each site. At BW, which had more extensive collecting, a grid was established and 5-10 soil samples were collected along transects oriented in respect to the grid. Soils were usually processed for CSM the following day using a soil dilution technique (Cavender \& Raper 1965a) which has been used extensively in the literature and is referred to as the "Cavender Method": hay infusion agar plates (3/sample) are poured 24 hours before plating the soils to allow some drying. The hay infusion medium (Raper 1984) is composed of $8 \mathrm{~g}$ of leached dried grass (usually Poapratensis), $1.5 \mathrm{~g}$ $\mathrm{KH}_{2} \mathrm{PO}_{4}, \quad 0.95 \mathrm{~g} \quad \mathrm{Na}_{2} \mathrm{HPO}_{4} .7 \mathrm{H}_{2} \mathrm{O}$, and $15 \mathrm{~g}$ agar/liter $\mathrm{H}_{2} \mathrm{O}$. The hay infusion has proved superior to defined media because it has a stimulating influence on spore germination and subsequent myxamoebal growth. Ten $\mathrm{g}$ soil is added to $90 \mathrm{ml} \mathrm{H}_{2} \mathrm{O}$ (1:10) in flasks and shaken 2 minutes; coarse particles are allowed to settle and $5 \mathrm{ml}$ of suspension is transferred to $7.5 \mathrm{ml}$ $\mathrm{H}_{2} \mathrm{O}$ (1.25 dilution), $0.5 \mathrm{ml}$ of this dilution is added to each plate (1:50 dilution factor) along with 5 drops of heavy Escherichia coli (strainsB/r or Raper 281) suspension, made by growing the bacteria for 12-24 hours on nutrient agar (tryptone, glucose, yeast extract) and then dispersing the bacteria in $\mathrm{H}_{2} \mathrm{O}$ using a hockey stick (bent glass rod); $3 \mathrm{ml}$ of $\mathrm{H}_{2} \mathrm{O}$ are used for each bacterial plate. The soil suspension and bacteria are uniformly distributed over the surface of the agar plate which is then returned to its original position on the laboratory bench. Lids are cracked open for 6-12 hours to evaporate excess liquid. CSM clones appear on the plate 3-5 days later. Identification can usually be made on the isolation plates. Clones are marked as they appear and counted after 6-7 days. The average number of clones/plate is multiplied by 50 to obtain numbers/g soil. Identifications and taxonomy are those described in Cavender \& Vadell (2006)

\section{Results and discussion}

The first two collections at BW in the fall of 2003 produced a total of 14 species (Table 3). Since previous collections in Ohio from woodlands had produced 10 and 11 species at 7 locations (Cavender \& Vadell 2006) and a maximum of 12 at one location (Sheick Hollow), these results indicated that BW had an unusual CSM species richness and was worthy of further study to determine total CSM diversity as well as features which make this diversity possible.

Subsequently, 15 more collections were made up until the fall of 2009. Over this period we found an average of 11.2 species per collection and 351 clones per gram of soil (Table 3). Two collections, early summer (27 June 2004) and early spring (26 March 2007), produced 15 species while a total of 19 species were found altogether. Individual soil samples have produced 10 species on one occasion and seven to eight species not uncommonly. There have been no other reports of this many species of CSM inhabiting a small temperate woodland (<40 ha.). The most species reported for a temperate forest region was 30 for the Smoky

Table 2 Features of Butterfly Woods at The Wilds.

\begin{tabular}{ll}
\hline Feature & Description \\
\hline Slope & NE \\
Tree diversity & 26 species: 62\%-Fraxinusamericana, Ulmusrubra, Lindera \\
& benzoin, Acer rubrum, Fagusgrandifolia, A. saccharum \\
& (other locations at The Wilds had 11-21 species) \\
Herbaceous understory diversity & 59 species (other locations at The Wilds had 12-31 species) \\
pH & $6.2-7.0$ (generally highest at bottom of slope) \\
Nutrients (N, P, K, Ca) (ppm) & $\mathrm{N}-4.28-32.25$ \\
& $\mathrm{P}-6-15$ \\
& $\mathrm{~K}-179-245$ \\
& $\mathrm{Ca}-919-2156$ \\
& $12.8-23.1 \%$ \\
Organic matter (surface) & Sandy Loam \\
\hline
\end{tabular}


Mountain National Park (Landolt et al.2006). Although the number of species at BW exceeded the average in Ohio, the density in number of clones per gram was not exceptional as Cavender \& Vadell (2006) reported an average of 437 clones/g and 8.7 species/site while Cavender \& Hopka (1986) reported 700 clones/g. Abundance, therefore, is not necessarily an indicator of high species diversity.

\section{Individual species distributions}

Comparison of the distribution of CSM at the state level with what is found in BW (Table 4) may help explain why so many CSM species can co-exist in BW. The species in Table 4 are listed in order of decreasing number of clones in BW. Overall the distribution is comparable to that of the state as a whole except for several interesting differences. At the state level CSM species were divided previously into four groups on the basis of numbers of clones and percent presence: very common $(4000-7300,>50 \%)$, common (400-1600, ca. 50\%), rare (70-220, $1-3 \%)$, and very rare $(1-60,<1 \%$; Cavender \& Vadell 2006). Three of the very common species are the same state-wide as in BW: Polysphondyliumviolaceum, P. pallidum, and Dictyosteliumminutum although their position is reversed. Dictyosteliummucoroides is the most common species state wide but it is only sixth most common at BW. Although high state-wide, some of the total for D. mucoroides is partially due to the fact that $D$. leptosomum and D. implicatum were not differentiated from D. mucoroides at the time most of the collections were made. Dictyosteliummucoroides is the most widespread and adaptable species on a global basis (Swanson et al. 1999) and will usually dominate in suboptimal habitats. The dominance of Polysphondyliumviolaceum at BW may be explained by its statistically significant greater abundance in Ohio in soils of higher $\mathrm{pH}$, very similar to those of BW (Cavender \& Hopka 1986). Polysphondyliumpallidum (third at BW), on the other hand, was significantly more abundant in acidic soils. Dictyosteliumminutum, another species more prevalent in acidic soils, especially with mor type humus, had the most clones at BW which has mull humus, however, this was mostly due to the presence of 275 clones from one sample. This sometimes occurs when isolating $D$. minutum, which becomes very abundant in hot spots (Cavender 1972). The common species e.g., D. lacteum, D. aureo-stipes, D.discoideum, and D. purpureum are the same, however, one common species state-wide, D. giganteum, is rare at BW. Again, comparable to $D$. mucoroides, this species tends to dominate where the habitat is suboptimal, particularly where there is disturbance (Kauffman 1986). A third species occurring in suboptimal and disturbed environments is D. Sphaerocephalum. It may owe its single occurrence (20 Nov08) to the past disturbances at BW. Polysphondylium album, another common species at BW, was only recently described and therefore not enumerated at the state level. Acytosteliumleptosomum, a rare state species but very rare in BW, was found to be most abundant across the state in acidic sandstone ravines which are more acid than the one in BW. Another state rare species, D. Policephalum, was not found at BW. This species generally inhabits flood plain and depressional forest in Ohio. Three of the 10 very rare state species, D. quercibrachium, $P$. candidum, and D.polycarpum, were found in BW, the latter occurring in Ohio only in a limestone ravine. This species was found in BW perhaps because of the ravine there. The other seven Ohio species were very localized, found only at one site and probably do not occur at BW. For example, Dictyosteliumaureum and D. rosarium were associated with a salt marsh, Acytosteliummagnuphorum with an acid bog, and $P$. filamentosum was in a swamp forest.

From the above results we can observe that a variety of species occur in BW that were shown to favour specific environmental niches in Ohio (Cavender \& Hopka 1986). BW is very favourable for CSM because it provides a variety of niches which promote this cooccurrence.

\section{Features promoting cellular slime mold occurrence at Butterfly Woods}

Since BW has been found to provide optimal habitat for CSM diversity in Ohio, it is important to carefully describe the features of 
Table 3 Cellular slime mold collections from ButterflyWoods, The Wilds (2003-2009), number of samples collected per sampling occasion, number of species collected per sampling occasion, number of clones collected per species per sampling occasion, total number of clones collected/gram of soil per sampling occasion, and relative density of each species across all sampling occasions $(\mathrm{Rd})$.

\begin{tabular}{|c|c|c|c|c|c|c|c|c|c|c|c|c|c|c|c|c|c|c|c|}
\hline Date collected & $\begin{array}{c}09 \\
\text { Sep } \\
2003 \\
\end{array}$ & $\begin{array}{c}26 \\
\text { Oct } \\
2003 \\
\end{array}$ & \begin{tabular}{|c|}
27 \\
Dec \\
2003 \\
\end{tabular} & 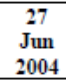 & \begin{tabular}{|c|}
22 \\
Apr \\
2005 \\
\end{tabular} & $\begin{array}{c}04 \\
\text { Sep } \\
2005 \\
\end{array}$ & $\begin{array}{c}31 \\
\text { Mar } \\
2006 \\
\end{array}$ & \begin{tabular}{|c|c|}
04 \\
May \\
2006 \\
\end{tabular} & \begin{tabular}{|c|c|}
26 \\
Mar \\
2006 \\
\end{tabular} & \begin{tabular}{|c|}
15 \\
Apr \\
2007 \\
\end{tabular} & $\begin{array}{c}20 \\
\text { Apr } \\
2007\end{array}$ & $\begin{array}{c}22 \\
\text { Nov } \\
2007\end{array}$ & $\begin{array}{c}19 \\
\text { Apr } \\
2008 \\
\end{array}$ & $\begin{array}{c}24 \\
\text { Jul } \\
2008 \\
\end{array}$ & $\begin{array}{c}20 \\
\text { Nov } \\
2008 \\
\end{array}$ & $\begin{array}{c}10 \\
\text { Sep } \\
2009\end{array}$ & \begin{tabular}{|c|}
25 \\
Sep \\
2009 \\
\end{tabular} & & \\
\hline $\begin{array}{l}\text { \# samples } \\
\text { collected }\end{array}$ & 10 & 5 & 5 & 10 & 9 & 8 & 9 & 8 & 8 & 9 & 5 & 10 & 6 & 5 & 7 & 6 & 6 & & \\
\hline \# species & 10 & 13 & 9 & 15 & 11 & 11 & 11 & 10 & 15 & 12 & 9 & 11 & 9 & 11 & 10 & 11 & 12 & $11.2(\mathrm{~g}$ & avg) \\
\hline Species & & & & & & & & & & & & & & & & & & Tot & Rd \\
\hline $\begin{array}{l}\text { Dictyostelium } \\
\text { minutum }\end{array}$ & 13 & 14 & 275 & 73 & 40 & 45 & 22 & 4 & 37 & 2 & 21 & 105 & 49 & 19 & 3 & 45 & 5 & 772 & 32.8 \\
\hline $\begin{array}{l}\begin{array}{l}\text { Polysphondylium } \\
\text { violaceum }\end{array} \\
\end{array}$ & 44 & 10 & 8 & 14 & 16 & 74 & 7 & 5 & 25 & 39 & 11 & 185 & 11 & 50 & 39 & 99 & 35 & 672 & 28.5 \\
\hline $\begin{array}{l}\begin{array}{l}\text { Polysphondylium } \\
\text { pallidum }\end{array} \\
\end{array}$ & 12 & 24 & 6 & 7 & 5 & 8 & 10 & 2 & 4 & 2 & 2 & 119 & 1 & 16 & 10 & 1 & 7 & 236 & 10.0 \\
\hline $\begin{array}{l}\text { Dictyostelium } \\
\text { purpureum }\end{array}$ & 5 & 3 & 3 & 0 & 2 & 14 & 0 & 0 & 2 & 1 & 0 & 11 & 16 & 6 & 13 & 15 & 23 & 114 & 4.8 \\
\hline $\begin{array}{l}\text { Dictyostelium } \\
\text { aureostipes }\end{array}$ & 3 & 2 & 0 & 6 & 8 & 6 & 0 & 3 & 1 & 31 & 4 & 20 & 2 & 7 & 0 & 5 & 2 & 100 & 4.2 \\
\hline $\begin{array}{l}\text { Polysphondylium } \\
\text { album. }\end{array}$ & 0 & 0 & 0 & 3 & 5 & 6 & 0 & 2 & 3 & 22 & 1 & 17 & 2 & 5 & 4 & 26 & 0 & 96 & 4.1 \\
\hline $\begin{array}{l}\text { Dictyostelium } \\
\text { mucoroides }\end{array}$ & 14 & 19 & 2 & 2 & 5 & 0 & 3 & 2 & 7 & 11 & 0 & 13 & 1 & 2 & 2 & 0 & 0 & 83 & 3.5 \\
\hline $\begin{array}{l}\text { Dictyostelium } \\
\text { discoideum }\end{array}$ & 3 & 1 & 2 & 1 & 8 & 5 & 7 & 1 & 1 & 8 & 2 & 0 & 0 & 4 & 3 & 3 & 3 & 52 & 2.2 \\
\hline $\begin{array}{l}\text { Dictyostelium } \\
\text { implicatum }\end{array}$ & 0 & 0 & 1 & 1 & 0 & 4 & 4 & 27 & 2 & 2 & 1 & 5 & 0 & 0 & 0 & 5 & 1 & 53 & 2.2 \\
\hline $\begin{array}{l}\text { Dictyostelium } \\
\text { lacteum }\end{array}$ & 4 & 1 & 4 & 1 & 7 & 2 & 1 & 0 & 1 & 3 & 1 & 2 & 2 & 9 & 0 & 4 & 5 & 47 & 2.0 \\
\hline Dictyostelium sp. I & 3 & 4 & 0 & 3 & 3 & 3 & 2 & 15 & 3 & 7 & 0 & 0 & 0 & 0 & 0 & 0 & 0 & 43 & 1.8 \\
\hline $\begin{array}{l}\text { Polysphondylium } \\
\text { candidum }\end{array}$ & 0 & 0 & 0 & 9 & 4 & 2 & 7 & 0 & 6 & 5 & 2 & 2 & 1 & 1 & 0 & 0 & 2 & 41 & 1.7 \\
\hline $\begin{array}{l}\text { Dictyostelium } \\
\text { giganteum }\end{array}$ & 2 & 0 & 0 & 0 & 0 & 0 & 3 & 0 & 1 & 0 & 0 & 0 & 0 & 0 & 3 & 1 & 5 & 15 & 0.6 \\
\hline $\begin{array}{l}\text { Dictyostelium } \\
\text { leptosomum }\end{array}$ & 0 & 0 & 0 & 2 & 0 & 0 & 0 & 0 & 1 & 0 & 0 & 2 & 0 & 1 & 3 & 0 & 1 & 10 & 0.4 \\
\hline $\begin{array}{l}\text { Dictyostelium } \\
\text { quercibrachium }\end{array}$ & 0 & 1 & 0 & 0 & 0 & 0 & 1 & 0 & 6 & 0 & 0 & 0 & 0 & 0 & 0 & 0 & 0 & 8 & 0.3 \\
\hline $\begin{array}{l}\text { Acytostelium } \\
\text { leptosomum }\end{array}$ & 0 & 1 & 1 & 1 & 0 & 0 & 0 & 0 & 0 & 0 & 0 & 0 & 0 & 0 & 0 & 0 & 1 & 4 & 0.2 \\
\hline $\begin{array}{l}\text { Dictyostelium } \\
\text { polycarpum }\end{array}$ & 0 & 1 & 0 & 4 & 0 & 0 & 0 & 0 & 0 & 0 & 0 & 0 & 0 & 0 & 0 & 0 & 0 & 5 & 0.2 \\
\hline Dictyostelium sp. 2 & 0 & 1 & 0 & 1 & 0 & 0 & 0 & 1 & 0 & 0 & 0 & 0 & 0 & 0 & 0 & 0 & 0 & 3 & \begin{tabular}{|l|}
0.1 \\
\end{tabular} \\
\hline $\begin{array}{l}\text { Dictyostelium } \\
\text { sphaerocephalum }\end{array}$ & 0 & 0 & 0 & 0 & 0 & 0 & 0 & 0 & 0 & 0 & 0 & 0 & 0 & 0 & 2 & 0 & 0 & 2 & 0.1 \\
\hline Total & 103 & 82 & 302 & 128 & 103 & 169 & 67 & 62 & 100 & 133 & 45 & 481 & 85 & 120 & 82 & 204 & 90 & 2356 & \\
\hline \# clones/g & 172 & 273 & 1007 & 213 & 191 & 352 & 124 & 129 & 278 & 416 & 225 & 802 & 236 & 400 & 195 & 567 & 250 & 351 (a & \\
\hline
\end{tabular}

this woodland as they appear to be those that favour the co-occurrence of CSM species. Some of these points have been discussed previously (Cavender \& Cavender 2004, 2005). Size: It is about 6 ha in area. This is a relatively small area, therefore we know from our study that this size or larger is adequate for preserving CSM diversity. Johnson Woods, also part of The Wilds has only four species of CSM (Table 1) and appears to be too small $(<6$ ha.) to preserve CSM diversity. The other three woods, Beech Hollow, Miller, and Rappelling, although also small remnants, appear to have high CSM diversity which would match that of BW if more collecting were done. Size may not be sufficient by itself for conserving CSM diversity, since the close proximity of other woodlands may be a contributing factor, as we believe the case to be for The Wilds. Disturbance: The environment around BW is extremely disturbed by strip mining and the upper portion of the woods has been affected. This undoubtedly has been detrimental. However, the northeast sloping part of the woods is intact. It may have had some agricultural disturbance in the past but since it was a source of water for the nearby farm, it may have been well protected, as evidenced by the large trees present and the well-developed herbaceous flora. Some disturbance may actually increase CSM diversity. For example, in Africa recovery of CSM diversity after slash and burn occurred well before the development of mature forest (Cavender et al. 1993). We also know that at least three species, Dictyosteliumsphaerocephalum, D. mucoroides, and D.giganteum are favoured in disturbed soils (Kauffman 


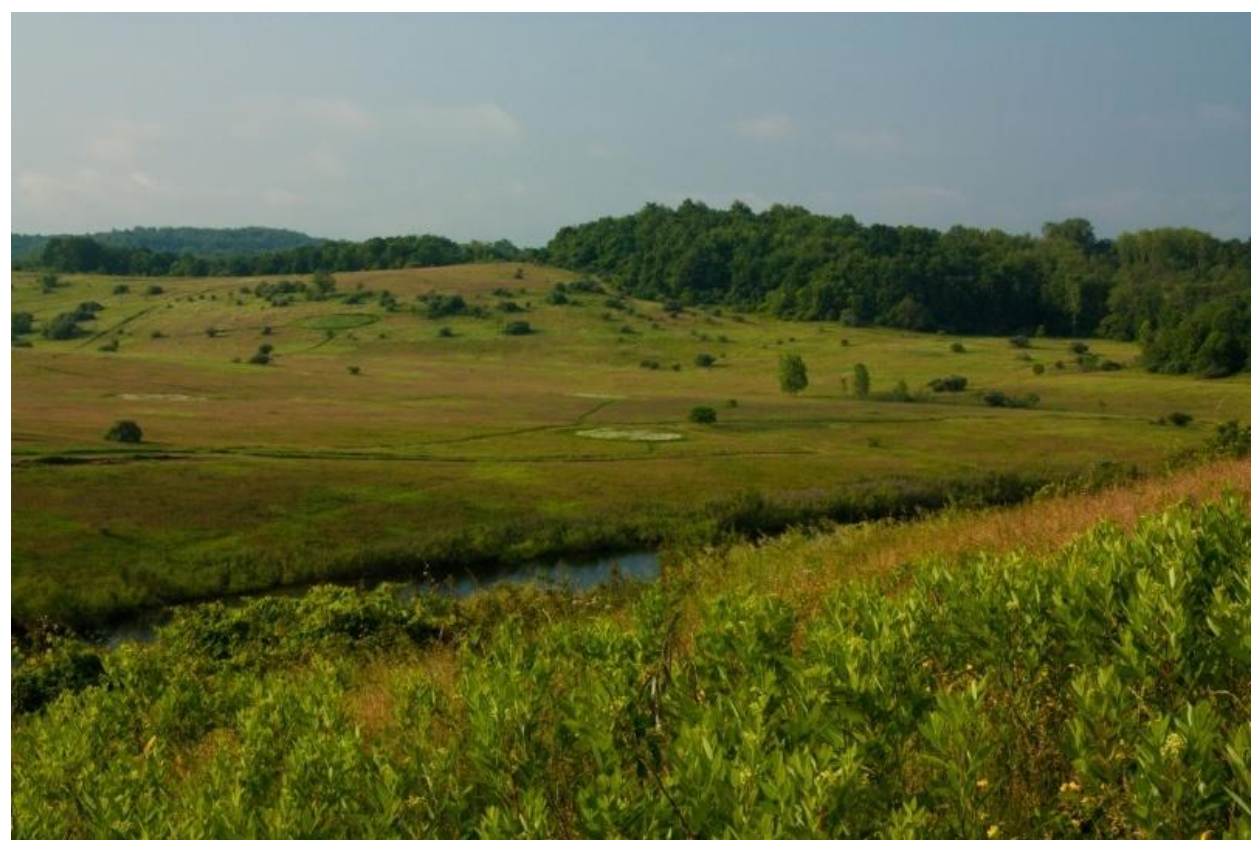

Fig. 2 - Butterfly Woods at The Wilds Ohio.

Table 4 Species, associated soil (acidic, neutral, or alkaline), Ohio total clone, total number of clones found at The Wilds and average relative density comparisons with other Ohio sites.

\begin{tabular}{|c|c|c|c|c|c|c|c|}
\hline Species & $\begin{array}{l}\text { Assoc. soil } \\
\text { pH }\end{array}$ & $\begin{array}{l}\text { Ohio } \\
\text { clones }\end{array}$ & total & $\begin{array}{l}\text { The Wilds } \\
\text { Total clones }\end{array}$ & $\begin{array}{l}\text { RD \% } \\
\text { Wilds }\end{array}$ & $\begin{array}{l}\text { RD } \\
\text { Ohio }\end{array}$ & $\%$ \\
\hline Dictyosteliumminutum & A & & 5310 & 772 & 32.8 & & 18.9 \\
\hline Polysphondyliumviolaceum & N-A & & 4102 & 672 & 28.5 & & 14.6 \\
\hline P. pallidum & A & & 6303 & 236 & 10 & & 22.4 \\
\hline D. purpureum & N-A & & 483 & 114 & 4.8 & & 1.7 \\
\hline D. aureo-stipes & A & & 1583 & 100 & 4.2 & & 5.6 \\
\hline D. mucoroides* & A & & 7279 & 83 & 3.5 & & 25.9 \\
\hline P. album & $\mathrm{N}-\mathrm{A}$ & & & 96 & 3.4 & & 0 \\
\hline D. discoideum & A & & 832 & 52 & 2.2 & & 3 \\
\hline D. implicatum & A & & 127 & 53 & 2.2 & & 0.45 \\
\hline D. $s p 1$ & N-A & & & 43 & 2.1 & & 0 \\
\hline D. lacteum & N-A & & 1012 & 47 & 2 & & 3.6 \\
\hline P. candidum & $\mathrm{N}-\mathrm{A}$ & & & 41 & 1.9 & & 0 \\
\hline D. giganteum & A & & 543 & 15 & 0.6 & & 1.9 \\
\hline D. leptosoтит & A & ----- & & 10 & 0.4 & & ------ \\
\hline D. quercibrachium & A & & 4 & 8 & 0.3 & & 0.03 \\
\hline Acytosteliumleptosomит & A & & 219 & 4 & 0.2 & & 0.8 \\
\hline D. polycarpum & N-A & & 4 & 5 & 0.2 & & 0.02 \\
\hline D. $s p 2$ & N-A & & & 3 & 0.15 & & 0 \\
\hline D. sphaerocephalum & A & & 141 & 2 & 0.1 & & 0.5 \\
\hline D. polycephalum & N-A & & 79 & 0 & 0 & & 0.3 \\
\hline D. aureum & N-A & & 52 & 0 & 0 & & 0.2 \\
\hline D. septentrionalis & A & & 31 & 0 & 0 & & 0.1 \\
\hline D. rosarium & $\mathrm{N}-\mathrm{A}$ & & 11 & 0 & 0 & & 0.04 \\
\hline P. tепиіssimuт & A & & 9 & 0 & 0 & & 0.03 \\
\hline D. magnuphorum & A & & 7 & 0 & 0 & & 0.025 \\
\hline P. filamentosum & A & & 3 & 0 & 0 & & 0.01 \\
\hline D. ohioensis & A & & 1 & 0 & 0 & & $<0.01$ \\
\hline TOTAL & & & 28135 & 2356 & & & \\
\hline
\end{tabular}


1986, Hammer 1984). Previous history: BW was not glaciated or inundated by post-glacial lakes. In Ohio, greatest plant diversity is in the unglaciated portion, particularly the area not flooded e.g., Adams County. On a state-wide basis, the highest CSM diversity was found in the unglaciated forests (Hopka 1972). Glaciation may have had a similar impact on CSM as it had on higher plants (e.g., driving species into protected refugia further south). Higher plant diversity: BW is a mixed mesophytic forest in the scheme of Braun (1950). These forests have the highest plant diversity in Ohio and they were found to have the highest CSM diversity (Hopka 1972). Plant diversity is believed to factor into CSM diversity because the number of species of both increases with a decrease in latitude (Cavender 1973). Slope aspect: BW has a northeast slope (Fig. 1). Of the eight physiographic regimes in Ohio studied by Cavender \& Hopka (1986), the NE slope was found to be optimal for CSM diversity. Northeast slopes typically have greater soil moisture and deeper humus. Ravine: A small ravine is present (Fig.1). In Ohio, ravines had some of the highest totals for number of species (Cavender \& Vadell 2006). Ravines are believed to be helpful to CSM by conserving moisture and providing protection from rapid temperature changes. Soil $\mathrm{pH}$ : The $\mathrm{pH}$ of the woods is variable from 6.2 to 7.0, generally increasing down the slope. CSM show a relationship between the abundance of different species and the acidity or alkalinity of the soil. For example, in Ohio, the species, Dictyosteliumpurpureum and Polysphondyliumviolaceum, are more abundant in soils with a higher $\mathrm{pH}$ while $P$. pallidum and $D$. minutum favour a more acid environment. The variation in soil $\mathrm{pH}$ at $\mathrm{BW}$ probably supports CSM coexistence. A $\mathrm{pH}$ near neutrality is known to positively affect bacterial abundance and diversity which may, in turn, have a corresponding positive effect on CSM abundance and diversity. Organic matter: CSM respond positively to decomposing organic matter in the form of leaf mould. Their numbers drop rapidly below the $\mathrm{O}$ horizon (Cavender \& Raper 1965b). The organic matter of BW soils is good (Table 2) and leaf litter is present year-round. Moisture: The northeast slope and good organic matter contribute to adequate moisture levels throughout the year; 15 to $30 \%$ moisture is necessary for reproduction by sporulation in CSM (Singh 1947).

Since individual dictyostelid species respond to variations in physiographic regime, the particular combination of niches (microhabitats) offered by Butterfly Woods appear to be those conducive to high species richness.

\section{Acknowledgements}

The authors would like to thank Shana Byrd, Corine Peugh and the staff at The Wilds for their support of this project. We also thank Catherine Bechtoldt with The Morton Arboretum for her help with formatting the manuscript.

\section{References}

Braun EL. 1950 - Deciduous forests of eastern North America. Blakiston, Philadelphia, Pennsylvania.

Cavender JC. 1972 - Cellular slime molds of eastern Canada. Canadian Journal of Botany 50, 1497-1501.

Cavender JC. 1973 - Geographical Distribution of Acrasieae. Mycologia 65, 10441054.

Cavender JC,Hopka C. 1986 - Distribution patterns of Ohio soil dictyostelids in relation to physiography. Mycologia 78, 825-831.

Cavender JC, Raper KB. 1965a - The Acrasieae in nature. I. Isolation. American Journal of Botany 52, 294296.

Cavender JC, Raper KB. 1965b - The Acrasieae in nature. II. Forest soil as a primary habitat. American Journal of Botany 52, 297-302.

Cavender JC, Vadell E. 2006 - Cellular slime molds of Ohio. Ohio Biological Survey.Columbus, Ohio.

Cavender JC, Bradshaw RA, Regner JP, Damio T. 1993 - Response of soil dictyostelid slime molds to agricultural disturbance in a tropical environment. Biotropica 25, 245-248.

Cavender N, Cavender JC. 2004 - Cellular slime molds in forest disturbance at The 
Wilds, southeastern Ohio. Abstract. Ohio Journal of Science 104(1), 40.

Cavender N, Cavender JC. 2005 - Factors affecting cellular slime mold diversity at The Wilds in southeastern Ohio. Abstract.Fifth International Congress of Systematic Ecology of Myxomycetes (ICSEM-5), Tlaxcala, Mexico, p.17.

Hammer CA. 1984 - Dictyostelids in agricultural soils. M.S. thesis, Ohio University, Athens, Ohio.

Hopka C. 1972 - A survey of the soil Acrasieae of Ohio.M.S. thesis, Ohio University, Athens, Ohio.

Kauffman GL. 1986 - Effects of organic matter and moisture content on dictyostelids in agricultural soil. M.S. thesis, University, Athens, Ohio.

Landolt JC, Stephenson SL, Cavender JC. 2006 - Distribution and ecology of dictyostelid cellular slime molds in Great Smoky Mountains National Park. Mycologia 98, 541-549.

Raper KB. 1984 - The Dictyostelids. Princeton, New Jersey: Princeton University Press.

Romeralo M, Cavender J, Landolt J, Stephenson S, Baldauf S. 2011 - An expandedphylogeny of social amoebas
(Dictyostelia)shows increasing diversity and new morphological patterns.BMC Evolutionary

Biology

11:84,doi:10.1186/1471-2148-11-84.

Schaap P, Winckler T, Nelson M, AlvarezCurto E, Elgie B, Hagiwara $\mathrm{H}$, Cavender JC, Milano-Curto A, Rozen DE, Dingermann T, Mutzel R, Baldauf SL. 2006 - Molecular phylogeny and evolution of morphology in the social amoebas. Science 314, 661-663. m nkdoi:10.1126/science. 1130670.

Singh BN. 1947 - Studies on soil Acrasieae. 2. The active life of Dictyostelium in soil and the influence thereon of soil moisture and bacterial food. Journal of General Microbiology1, 361-367.

Stephenson MA. 1995 - The taxonomy and ecology of dictyostelid cellular slime molds in a small watershed at the Ridges, Athens, Ohio. M.S. thesis, Ohio University, Athens.

Stout WE. 1918 - Geology of Muskingum County.Reprinted 1947.Ohio Geological Survey.351 p.

Swanson AR, Vadell, EM, Cavender JC. 1999 - Global distribution of forest soil dictyostelids. Journal of Biogeography 26, 133-148. 